\title{
ANALYSIS OF MOTOR-GRADER LOADING ON THE BASIS OF FRACTAL DIMENSION
}

\begin{abstract}
A. Polyarus, Prof., D. Sc. (Eng.), R. Paschenko, Prof., D. Sc. (Eng), E. Poliakov, Ph. D. (Eng.), A. Lebedinskyi, student, Kharkov National Automobile and Highway University

Abstract. The possibility of fractal dimension application for analysis of grader loading modes is considered in the article. The fractal dimensions of experimental dependences of load on the coupling pin of the grader at its different working conditions are calculated. It is determined that the magnitude of the fractal dimension allows to estimate the highest and lowest load of the grader.
\end{abstract}

Key words: fractal dimension, grader blade, load mode.

\section{АНАЛІЗ НАВАНТАЖЕННЯ АВТОГРЕЙДЕРА НА ОСНОВІ ФРАКТАЛЬНОЇ РОЗМІРНОСТІ}

\author{
О.В. Полярус, проф., д.т.н., Р.Е. Пащенко, проф., д.т.н., С.О. Поляков, к.т.н., \\ А.В. Лебединський, студент, \\ Харківський національний автомобільно-дорожній університет
}

\begin{abstract}
Анотація. Розглянуто можливість використання фрактальної розмірності для аналізу режимів навантаження автогрейдера. Розраховано фрактальні розмірності експериментальних залежностей навантаження на шворні автогрейдера за різних робочих умов автогрейдера. Показано, що величина фрактальної розмірності дозволяє оцінити найбільші та найменші навантаження автогрейдера.
\end{abstract}

Ключові слова: фрактальна розмірність, відвал автогрейдера, режим навантаження.

\section{АНАЛИЗ НАГРУЗКИ АВТОГРЕЙДЕРА НА ОСНОВЕ ФРАКТАЛЬНОЙ РАЗМЕРНОСТИ}

\author{
А.В. Полярус, проф., д.т.н., Р.Э. Пащенко, проф., д.т.н., \\ Е.А. Поляков, к.т.н., А.В. Лебединский, студент, \\ Харьковский национальный автомобильно-дорожный университет
}

\begin{abstract}
Аннотация. Рассмотрена возможность использования фрактальной размерности для анализа режимов нагрузки автогрейдера. Рассчитаны фрактальные размерности экспериментальных зависимостей нагрузки на шкворне при различных условиях работы автогрейдера. Показано, что величина фрактальной размерности позволяет оценить наибольшие и наименьшие нагрузки автогрейдера.
\end{abstract}

Ключевые слова: фрактальная размерность, отвал автогрейдера, режим нагрузки.

\section{Introduction}

The main working body of any motor-grader (grader) is a fully steerable blade with knives mounted at an angle to its longitudinal axis. Depending on the soil structure the grader blade is under the influence of alternating dynamic loads. In its turn the impact of loads can lead to the machine failures due to the appearance of cracks in metal structures. In addition to the soil structure, the load blade grader is also influenced by the parameters of its work, such as grader blade deflection, turning the angle of the blade, rotation frequency of the motor shaft, etc. The influence of these parameters can be investigated by using the vibration diagnostic 
methods. Various parameters of the machine lead to different modes of dynamic loads. The level and nature of the vibrations acting on the machine construction due to alternating loads can be estimated by analyzing the time-stress dependences on the grader coupling pin.

\section{Analysis of publications}

Investigation of earth-moving machines parameters is carried out to predict the possible malfunctions of their work. In this case various vibration diagnostics methods are used and some of them are presented in [1]. The research results presented in [2] show that it is possible to estimate the dynamic forces that act on the metal structure by using the results of dynamics of earth-moving machines analysis with a sharp increase in the resistance of movement. To carry out such an analysis it is necessary to obtain the original data about loads on the elements of machines received in different modes of their operation. In [3] the possibility of the phase portraits application for classification of grader load modes is considered. On the basis of experimental data describing the loads on the grader coupling pin the phase portraits for different modes of its work were constructed.

\section{Purpose and problem statement}

It is expediently the determination of grader load modes to carry out on the basis of experimentally obtained signal implementations which describe the load on the grader coupling pin. In this case, different load modes lead to various forms of recorded signals. The value of the fractal dimension (FD) [4] can be the characteristic of signal shape and the contrast of these shapes due to the loading on the grader coupling pin, in turn, leads to different values of FD. Therefore, the analysis of the possibility of FD using for estimation of load on grader coupling pin is of practical importance.

The aim of the article is estimation of fractal dimension usability for determination of grader load mode changes.

\section{Obtaining the experimental data}

An essential element of grader is a ball coupling pin through which the tractive forces from the drive wheels to the grader blade during performing of work operations are transmited. Therefore, it is advisable to estimate the loads acting on this element of grader. For this purpose, the field measuring experiments were carried out on the test area of our university. As a research facility the grader DZK-251 produced at Kriukov's Railway Car Building Plant was used. The procedure of experimental research conducting and measuring system that was used at the same time are described in [5]. Measurements of stress on the grader pin were performed with using of strain gauge transducers (sensors).

Changing parameters of grader during the experiments are shown in Fig. 1.

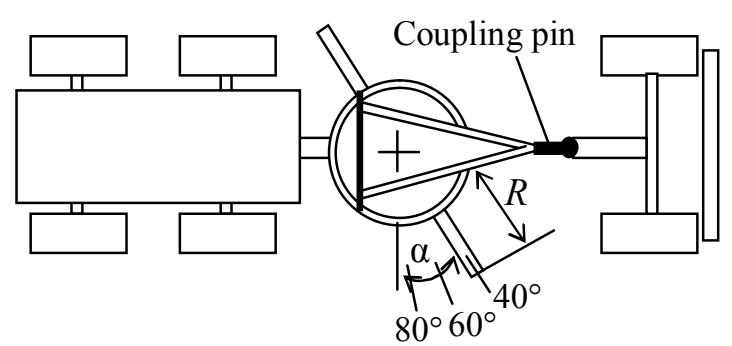

Fig. 1. Changing parameters of motor-grader

In Fig. 1 the letter $\alpha$ means grader blade rotation angle and $R$ - grader blade deflection. The figure also shows the point of load measurement on the pin.

During the experiments the influence of various positions of the grader blade at the stress arising on the grader pin was evaluated. The grader parameters were changed as follows: grader blade deflection $(R)$ was equal to $0 \mathrm{~m}, 0,7 \mathrm{~m}$ and $1,4 \mathrm{~m}$; blade angle of rotation $(\alpha)-40^{\circ}, 60^{\circ}$ and $80^{\circ}$; number of the motor shaft revolutions $(f)-$ $900 \mathrm{rev} / \mathrm{min}, 1100 \mathrm{rev} / \mathrm{min}$ and $1300 \mathrm{rev} / \mathrm{min}$. Indications of the sensors in the form of digital data from the measurement system were recorded in the permanent memory of the computer. In [3], all the time dependences of the stress $(\sigma, \mathrm{MPa})$ on the grader pin from variable parameters outlined above were presented and detailed analysis of these temporary implementations was carried out. In this paper, for example, we'll adduce only temporary dependences of stresses (Fig. 2): on the grader pin (in voltage) when grader blade deflection $(R)$ is respectively equal to $0 \mathrm{~m} \mathrm{(a)}, 0,7 \mathrm{~m} \mathrm{(b)}$ and $1,4 \mathrm{~m}$ (c) for fixed values of the blade angle $\left(\alpha=80^{\circ}\right)$ and the number of the motor shaft revolutions $(f=1300 \mathrm{rev} / \mathrm{min})$. The nature of time realizations for the other variable parameters is similar to those which are shown in Fig. 2.

In the figures on the ordinate $Y$ the stress on the grader pin $(\sigma, \mathrm{MPa})$ is represented and on the 
horizontal axis $I$ - execution time of work operations. In this case the value of $I=1 \times 104$ corresponds to the time $t=10 \mathrm{~s}$. The time $t=10 \mathrm{~s}$ corresponds to the value of $I=1 \times 10^{4}$.

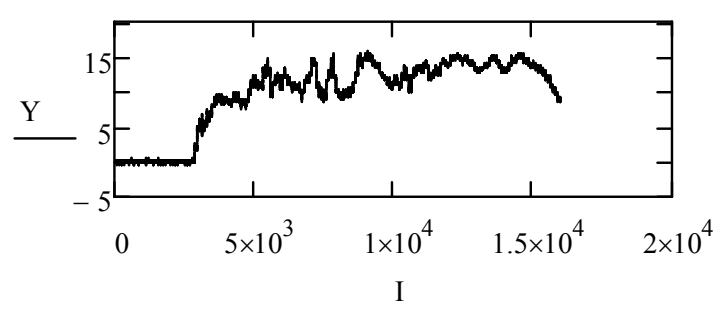

a

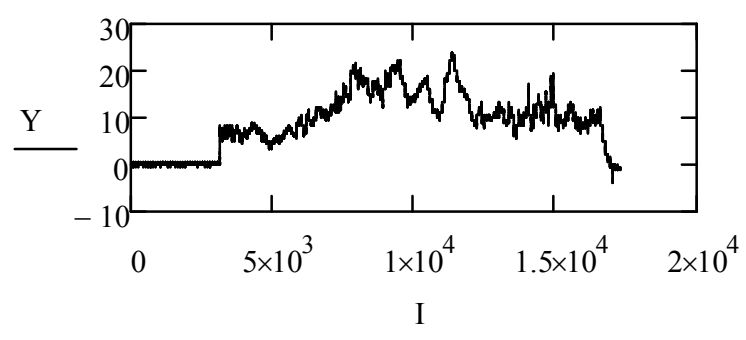

b

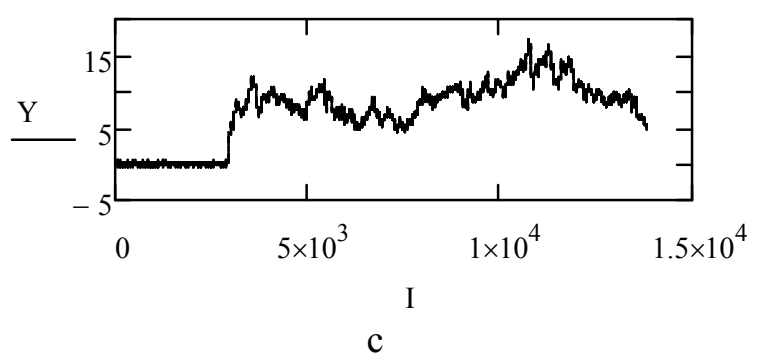

Fig. 2. The time realizations of stress signals on grader pin at $R=0 \mathrm{~m} \mathrm{(a),} R=0,7 \mathrm{~m} \mathrm{(b),}$ $R=1,4 \mathrm{~m}(\mathrm{c})$

Fig. 2 shows that at the first $2-3$ seconds grader was working without interaction with the ground and the load on the pin was minimal. The stress on the pin was increasing abruptly during the interaction of the blade and the ground. Later the load signal on the pin was changed irregularly and had an indented character. It should be noted that the indented nature of the stress changing is practically independent of the grader blade deflection.

Thus, from the analysis of the stresses on the pin it can be concluded if there was a load on the motor grader or it was working without load. However, over the time realizations of stresses it is practically impossible to determine under what parameters of grader the load is maximal since the maximum value of the signal amplitude is almost the same and the nature of its changes is indented at any parameters of grader.
As well as in the study of stresses at the grader blade deflection during fulfillment of working operations at different turning angle of the blade the stress amplitude on the pin is increased and has an indented character when the blade interacts with a soil.

The character of time realizations of the stress on the grader pin at different frequency of the motor shaft which is given in [3] doesn't differ from the character of time realizations that has been shown in the Fig. 2. Initially, the work operations are done with no load and then the stresses on the pin are increasing abruptly and have an irregular character.

Thus it can be easily defined the time of motorgrader loading occurrence with the help of time realizations of loadings (by an abrupt increase in the stress amplitude), however, it is hardly to determine the relationship between motor-grader loading conditions and its parameters as a part of the stress time realizations of working operations. For analysis of signal forms that describe the load on the grader pin we'll use the value of the fractal dimension.

\section{Calculation of fractal dimension}

In practice, the dimension of Hausdorf- Besicovitch $D[6]$ is often used for estimation of fractal characteristics of various structures

$$
D=\lim _{\varepsilon \rightarrow 0} \frac{\log N(\varepsilon)}{\log \left(\frac{1}{\varepsilon}\right)},
$$

where $N(\varepsilon)$ - number of covering elements; $\varepsilon-$ the side length of covering element.

All existing FD calculation methods include the calculation of volume, area or length of the fractal shape and its changes during scaling.

The method of the fractal dimension determining with using of signals covering by squares comprises the following steps [7].

1. Some value of $\varepsilon$ is defined, the time domain of the source data existence is divided into squares with a side $\varepsilon$ and the number of squares that covered all the known points (Fig. 3) are calculated. As a result, one value $N(\varepsilon)$ is obtained. 


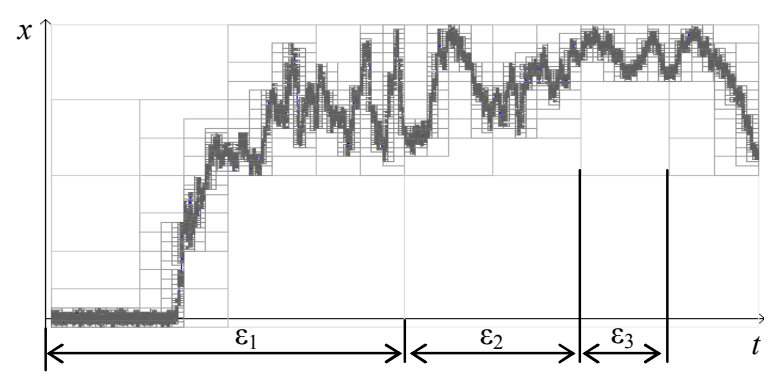

Fig. 3. Example of arrangement of the original sample covering

2. Assume that the calculations of $N(\varepsilon)$ were performed for different lengths of the side $\varepsilon$ (at Fig. 3 these values are $\varepsilon_{1}, \varepsilon_{2}=\varepsilon_{1} / 2, \varepsilon_{3}=\varepsilon_{1} / 4$ ). As it follows from the definition of FD [4], for small values of $\varepsilon$ the number of the covering elements $N(\varepsilon)$ should be equal to $\sim \varepsilon^{-D}$ and in this case $\log N(\varepsilon)=-D \cdot \log \varepsilon$. Now, with using of the obtained data the dependence $\log N(\varepsilon)$ versus $\log \left(\frac{1}{\varepsilon}\right)$ (Fig. 4) is plotted.

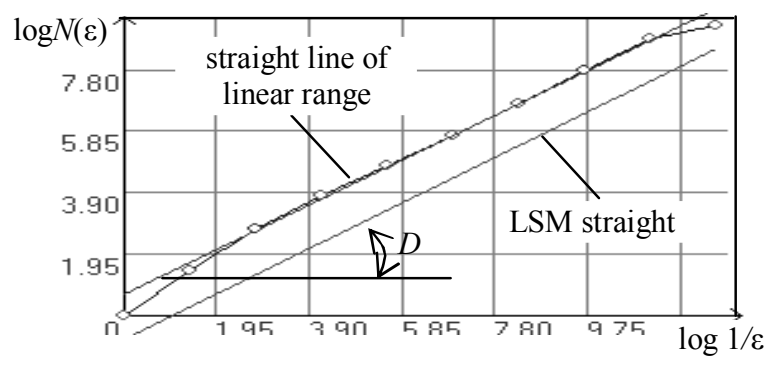

Fig. 4. The determination of Hausdorf-Besicovitch dimension with the use of covering method

3. The FD estimating is reduced to the search of «the most linear» area of the relationship between $\log N(\varepsilon)$ and $\log 1 / \varepsilon$; construction of the linear approximation of the form $\log N(\varepsilon)=$ $=-b \cdot \log \varepsilon+\mathrm{C}$ in this area, for example, by using of least squares method (LSM) [8]; FD estimation by evaluation of LSM line slope.

It should be noted that the choice of the most linear area in this algorithm is a difficult thing to formalize. Approximation of a linear part of the plot with using of LSM does not always produce reliable results. The straight line plotted on the basis of linear approximation for 10 points (LSM straight line) is shown in Fig. 4. In addition, another straight line is depicted at the same figure according to the selected 7 points when choosing the linear range of the plot (straight line area). It can be seen that the slopes of the lines do not differ significantly, however, FD is calculated more precisely when choosing linear range. Thus it needs to calculate the slope of approximating line using linear range of plot of $\log N(\varepsilon)$ as a function of $\log 1 / \varepsilon$.

\section{Analysis of grade loads using the fractal dimension}

Let's consider the possibility of FD using for the analysis of grader load. For this purpose, we calculate the values of the FD for the time realizations of stresses on the pin at different grader parameters (grader blade deflection, grader blade rotation angle, frequency of the motor shaft). The fractal dimension was calculated by using of the method described above.

The FD (D) dependences on the grader blade rotation angle with blade deflection $R=0 \mathrm{~m}$ and frequency of the motor shaft: $f=900 \mathrm{rev} / \mathrm{min}$ (solid line), $f=1100 \mathrm{rev} / \mathrm{min}$ (dotted line) and $f=1300 \mathrm{rev} / \mathrm{min}$ (dash-and-dot line) are shown in Fig. 5.

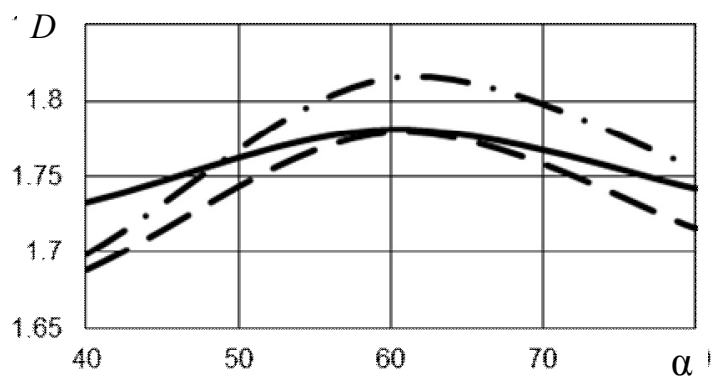

Fig. 5. FD dependences on the grader blade deflection at $R=0 \mathrm{~m}$

As it can be seen from the curves in Fig. 5, the maximum value of FD and consequently the greatest unevenness of time stress realizations occurs when the grader blade rotation angle value is equal to $\alpha=60^{\circ}$. Moreover, the greatest FD value is fixed when the frequency of the motor shaft reaches the value of $f=1300 \mathrm{rev} / \mathrm{min}$. The minimum values of FD for three curves are observed at $\alpha=40^{\circ}$. However, in contrast to the greatest FD values among the maximum values, the greatest FD values among the minimum values were fixed at $f=900 \mathrm{rev} / \mathrm{min}$. Also, as it follows from Fig. 5, increasing of the grader blade deflection more than $60^{\circ}$ leads to the FD decrease.

Fig. 6 shows that similar behavior is observed when the grader blade deflection value is $R=1,4 \mathrm{~m}$. However, the highest values are obtained at two angles of blade deflection $\alpha=40^{\circ}$ 
and $\alpha=60^{\circ}$, but not at a single one as it was previously.

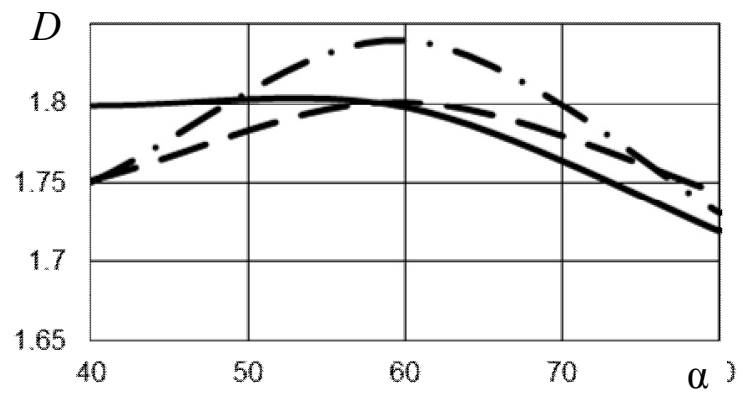

Fig. 6. FD dependences on grader blade deflection at $R=1,4 \mathrm{~m}$

However, the FD behavior differs from the cases examined above when grader blade deflection value is $R=0,7 \mathrm{~m}$ (Fig. 7).

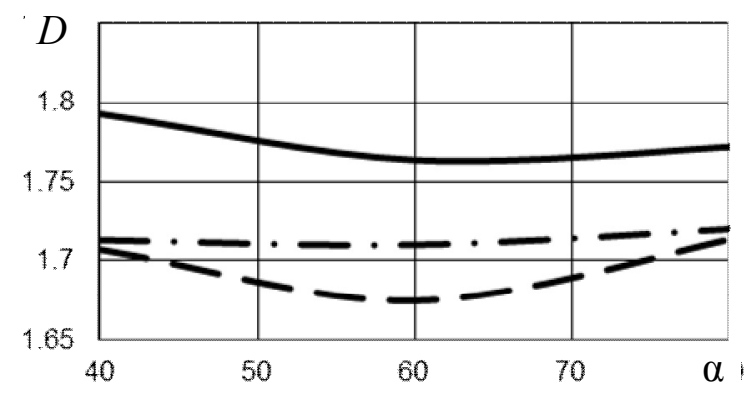

Fig. 7. FD dependences on grader blade deflection at $R=0,7 \mathrm{~m}$

Fig. 7 shows that FD is less dependent on the grader blade deflection and at frequency of the motor shaft $f=1300 \mathrm{rev} / \mathrm{min}$ it practically doesn't change. The maximum values of FD were obtained when $f=900 \mathrm{rev} / \mathrm{min}$, but the minimum values correspond to $\alpha=60^{\circ}$. Also the minimum values of $\mathrm{FD}$ were calculated at $f=1100 \mathrm{rev} / \mathrm{min}$.

Thus the analysis of FD values for various grader blade deflections showed that when grader work operations are in progress the maximum loads (unevenness of initial signal) are observed at $\alpha=60^{\circ}, f=1300 \mathrm{rev} / \mathrm{min}$ and $R=1,4 \mathrm{~m}$, and minimum - at $f=1100 \mathrm{rev} / \mathrm{min}$ and $R=0,7 \mathrm{~m}$. Let's consider the FD of time stress realizations on the pin for other grader parameters.

The FD dependences on grader blade deflection at blade rotation angle $\alpha=40^{\circ}$ and frequency of the motor shaft $f=900 \mathrm{rev} / \mathrm{min}$ (solid line), $f=1100 \mathrm{rev} / \mathrm{min}$ (dotted line) and $f=1300 \mathrm{rev} / \mathrm{min}$ (dash-and-dot line) are presented in Fig. 8. Fig. 8 shows that with the in- creasing of grader blade deflection the FD value also increases due to greater unevenness of measured signals. The maximum FD values and consequently the big loads were fixed at $f=900 \mathrm{rev} / \mathrm{min}$.

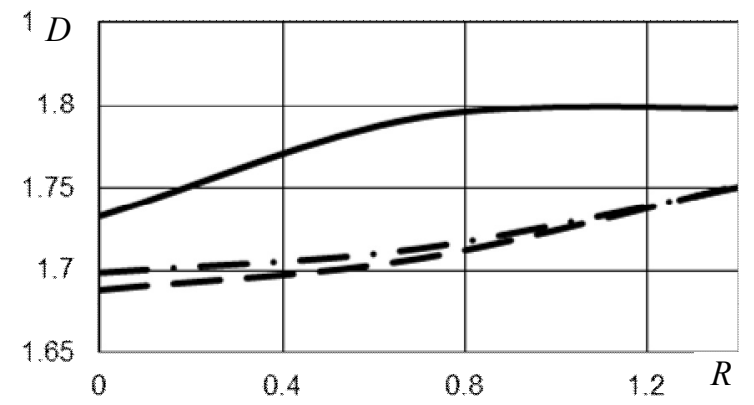

Fig. 8. FD dependences on grader blade deflection at $\alpha=40^{\circ}$

Meanwhile, when the grader blade rotation angle is $\alpha=60^{\circ}$, the FD minimum value occurs at grader blade deflection value $R=0,7 \mathrm{~m}$ for any frequency of the motor shaft value (Fig. 9) and FD minimum value - at $f=1100 \mathrm{rev} / \mathrm{min}$. Thus, the minimum loads of grader will be received when its blade deflection $R=0,7 \mathrm{~m}$ and $f=1100 \mathrm{rev} / \mathrm{min}$.

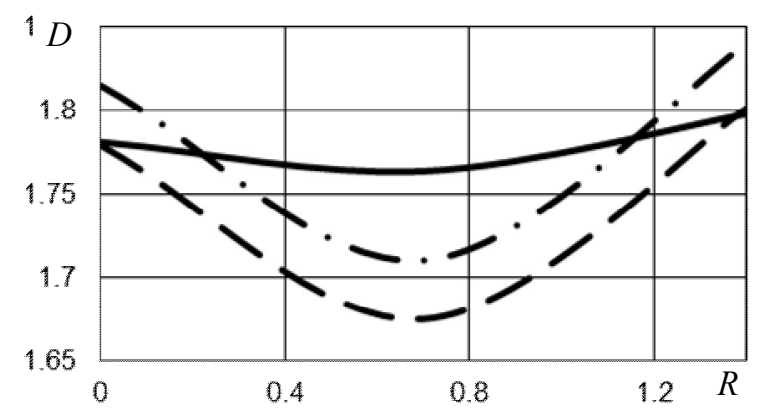

Fig. 9. FD dependences on grader blade deflection at $\alpha=60^{\circ}$

It should be noted that similar FD behavior is held at $f=1100 \mathrm{rev} / \mathrm{min}$ and $f=1300 \mathrm{rev} / \mathrm{min}$ (Fig. 10) when $\alpha=80^{\circ}$ but at $f=900 \mathrm{rev} / \mathrm{min}$ the maximum value of $\mathrm{FD}$ was received at $R=0,7 \mathrm{~m}$.

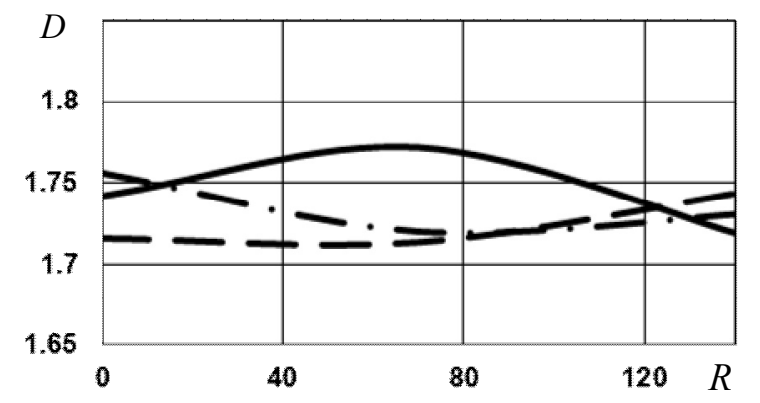


Fig. 10. FD dependences on grader blade deflection at $\alpha=80^{\circ}$

Thus analysis of dependences of FD values on grader blade deflection has revealed that the maximum FD values were achieved at $f=900 \mathrm{rev} / \mathrm{min}$ for the all grader blade rotation angles and the minimum value at $\alpha=60^{\circ}$, $f=1100 \mathrm{rev} / \mathrm{min}$ and $R=0,7 \mathrm{~m}$.

The dependences of FD values on the frequency of the motor shaft at grader blade rotation angle at $\alpha=40^{\circ}$ and grader blade deflection at $R=0 \mathrm{~m}$ (solid line), $R=0,7 \mathrm{~m}$ (dotted line) и $R=1,4 \mathrm{~m}$ (dash-and-dot line) are illustrated in Fig. 11.

As it follows from Fig. 11, the greatest values of FD are observed at $f=900 \mathrm{rev} / \mathrm{min}$ and the minimum values - at $f=1100 \mathrm{rev} / \mathrm{min}$ for any grader blade deflection value. The minimum FD value was fixed at $f=1100 \mathrm{rev} / \mathrm{min}$ and $R=0 \mathrm{~m}$.

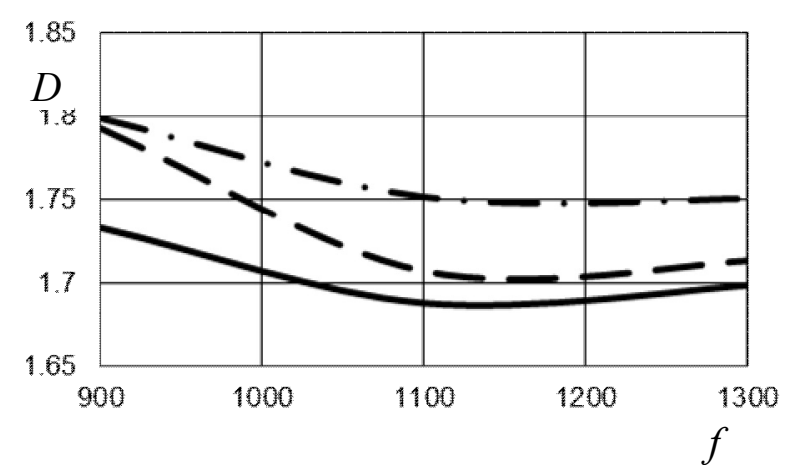

Fig. 11. FD dependences on frequency of the motor shaft at $\alpha=40^{\circ}$

Fig. 12 shows that at grader blade rotation angle $\alpha=60^{\circ}$ the minimum FD values also occur at $f=1100 \mathrm{rev} / \mathrm{min}$, however the maximum $\mathrm{FD}$ values were not fixed at $f=900 \mathrm{rev} / \mathrm{min}$ but they were detected at $f=1300 \mathrm{rev} / \mathrm{min}, R=0 \mathrm{~m}$ and $R=1,4 \mathrm{~m}$.

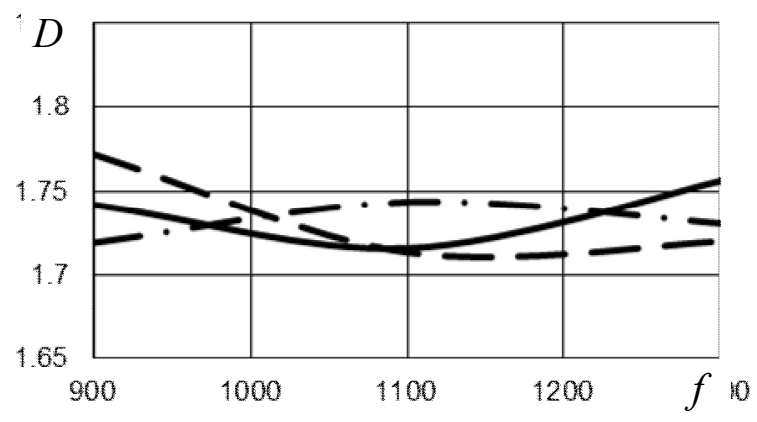

Fig. 12. FD dependences on frequency of the motor shaft at $\alpha=60^{\circ}$

The significant differences in FD values behavior occur at grader blade rotation angle value $\alpha=80^{\circ}$ (Fig. 13). In this case the spread of FD values is insignificant, i. e. it depends less on frequency of the motor shaft. In addition, it's difficult to estimate the maximum and minimum FD values at various frequency of the motor shaft and grader blade deflection values, because practically they don't differ.

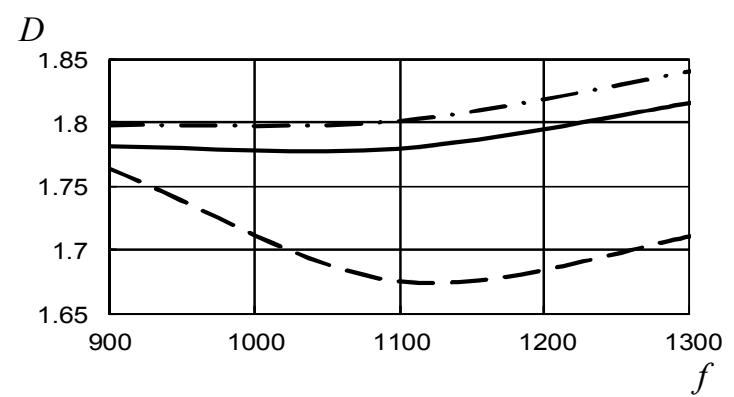

Fig. 13. FD dependences on frequency of the motor shaft at $\alpha=80^{\circ}$

Thus analysis of dependence of FD values on frequency of the motor shaft showed that the minimum FD values can be seen at $f=1100 \mathrm{rev} / \mathrm{min}, \alpha=60^{\circ}, R=0,7 \mathrm{~m}$, and the maximum values - at $f=900 \mathrm{rev} / \mathrm{min}, \alpha=40^{\circ}$ and $R=1,4 \mathrm{~m}$ and also at $f=1300 \mathrm{rev} / \mathrm{min}$, $\alpha=60^{\circ}$ and $R=1,4 \mathrm{~m}$.

\section{Conclusions}

The calculations of FD can be used for numerical estimation of irregularities of signals received from the sensors mounted on motorgrader pin.

Analysis of FD of experimental stress signals measured on motor-grader pin showed that its value depends on grader parameters when work operations are in progress.

Analysis of dependences of FD values on blade rotation angle, grader blade deflection and frequency of the motor shaft showed that when work operations are in progress the minimum loadings occur at $\alpha=60^{\circ}, \quad R=0,7 \mathrm{~m} \quad$ и $f=1100 \mathrm{rev} / \mathrm{min}$ and the maximum loadings - at $\alpha=40^{\circ}, \alpha=60^{\circ}, R=1,4 \mathrm{~m}$ и $f=900 \mathrm{rev} / \mathrm{min}$.

During further research it is advisable to consider the possibility of the fractal dimension using for the analysis of phase portraits of stress signals on motor-grader pin.

In the further work it is necessary to assess the possibility of using of the work results to improve the methods for determining grader oper- 
ating modes used in current normative documents.

\section{References}

1. Барков А.В. Мониторинг и диагностика роторных машин по вибрации / А.В. Барков, Н.А. Баркова, А.Ю. Азовцев. - С.Пб.: Изд. СПМТУ, 2000. - 158 с.

2. Холодов А.М. Динамика землеройнотранспортных машин при резком возрастании сопротивлений / А. М. Холодов // Труды ХАДИ. - 1960. - Вып. 22. C. 71-81.

3. Определение режима нагрузки автогрейдера с использованием фазовых портретов / А.В. Полярус, Р.Э. Пащенко, Е.А. Поляков, Я.С. Бровко // Строительство, материаловедение, машиностроение: сб. науч. тр. - 2013. - Вип. 72. C. $160-169$.

4. Пащенко Р.Э. Основы теории формирования фрактальных сигналов / Р.Э. Пащенко. - Харьков: ХООО «НЭО “ЭкоПерспектива"», 2005. - 296 с.

5. Шевченко В.А. Экспериментальная оценка влияния положения грейдерного отвала на нагрузки, действующие в основной раме автогрейдера ДЗК-251 / В.А. Шевченко, А.А. Резников, В.В. Крецул // Вестник ХНАДУ: сб. науч. тр. - 2010. Вып. 49. - С. 62-66.

6. Федер Е. Фракталы / Е. Федер. - М.: Мир, 1991. - $254 \mathrm{c}$.

7. Малинецкий Г.Г. Современные проблемы нелинейной динамики / Г.Г. Малинецкий, А.Б. Потапов. - М.: Едиториал УРСС, 2002. $-360 \mathrm{c}$.

8. Львовский Е.Н. Статистические методы построения эмпирических формул / Е.Н. Львовский. - М.: Высшая школа, 1988. - 240 c.

\section{References}

1. Barkov A.V., Barkova N.A., Azovtsev A.Yu. Monitoring $i$ diagnostika rotornykh mashin po vibratsii [Monitoring and diagnostics of rotor machines by vibration], Sankt-
Peterburg, SPMTU Publ., 2000. 158 p.

2. Kholodov A.M. Dinamika zemleroynotransportnykh mashin pri rezkom vozrastanii soprotivleniy [Dynamics of earthmoving - transport machines with a sharp increase of resistance]. Trudy KhADI. 1960. Vol. 22. pp. 71-81.

3. Polyarus A.V., Pashchenko R.E., Polyakov Ye.A., Brovko Ya.S. Opredelenie rezhima nagruzki avtogreydera $s$ ispolzovaniem fazovykh portretov [Determination of load regime of grader with using of the phase portraits]. Stroitelstvo, materialovedenie, mashinostroenie: sbornik nauchnykh trudov. 2013. Vol. 72. pp. 160-169.

4. Pashchenko R.E. Osnovy teorii formirovaniya fraktalnykh signalov [Fundamentals of the theory of fractal signal creating]. Kharkov, KhOOO «NEO "EkoPerspektiva"» Publ., 2005. 296 p.

5. Shevchenko V.A., Reznikov A.A., Kretsul V.V. Eksperimentalnaya otsenka vliyaniya polozheniya greydernogo otvala na nagruzki, deystvuyushchie $v$ osnovnoy rame avtogreydera DZK-251 [Experimental estimation of grader blade position acting in main frame of autograder ]. Vestnik KhNADU. 2010. Vol. 49. pp. 62-66.

6. Feder Ye. Fraktaly [Fractals]. Moscow, Mir Publ., 1991. 254 p.

7. Malinetskiy G.G., Potapov A.B. Sovremennye problemy nelineynoy dinamiki [The modern problems of nonlinear dynamics]. Moscow, Yeditorial URSS Publ., 2002. 360 p.

8. Lvovskiy Ye.N. Statisticheskie metody postroeniya empiricheskikh formul [The statistical methods of empirical formulas building]. Moscow, Vysshaya shkola Publ., 1988. $240 \mathrm{p}$.

Рецензент: В.А. Шевченко, доцент, к.т.н., ХНАДУ. 